\title{
O apelo à ordem nos telejornais policiais
}

\author{
Call to social order in the police news programs
}

\section{Fábio Ribeiro ${ }^{a}$}

Resumo Este trabalho é fruto de uma investigação sobre o telejornalismo policial, caracterizando-o e situando-o inicialmente num universo de constrições tanto internas ao campo como exteriores a ele. Entende-se que esses elementos estruturais em grande medida explicam a forma e o conteúdo do que é transmitido pelos programas desse subgênero midiático e servirá como preâmbulo analítico para a explicitação dos elementos principais contidos nos discursos veiculados ali. Através da análise empírica de determinadas edições nacionais dos programas Brasil Urgente (Band) e Cidade Alerta (Record), teremos referência para mostrar em que sentido pode-se afirmar que os discursos emanados dos telejornais policiais, frutos das condições de produção aqui analisadas, são de caráter moralista e punitivista.

Palavras-chave Telejornalismo policial. Moralismo. Comunicação de massa. Mídia: aspectos sociais.

Abstract This work is part of an investigation about the phenomenon of police telejournalism, characterizing it and situating it initially in a universe of constrictions both internal to the field and external to it. It is understood that these structural elements to a large extent explain the form and content of what is transmitted by the programs of this media subgenre and will serve as an analytical preamble for the explication of the main elements contained in the discourses conveyed there. Through the empirical analysis of certain national editions of the Brasil Urgente (Band broadcaster) and Cidade Alerta (Record broadcaster) programs, we will have reference to show in what sense it can be affirmed that the discourses emanating from the police news, fruits of the conditions of production analyzed here, are of moralistic and punitive character.

Keywords Police telejournalism. Moralism. Mass communication. Media: social aspects.

a Mestre e doutorando em Ciências Sociais pela UFJF. Membro do Núcleo de Pesquisa sobre Preconceito, Autoritarismo e Ideologia do PPGCSO/UFJF. Desenvolve pesquisa sobre a estrutura e reprodução de ideologia em classes populares. 


\section{INTRODUÇÃO}

Apesar da cada vez maior presença da Internet e das demais tecnologias recentes na produção e veiculação de entretenimento informativo, a televisão ainda ocupa grande espaço nas vidas das pessoas em nosso país, enquanto veículo privilegiado no que diz repeito à capacidade de pautar a agenda pública $\mathrm{e}$ conformar o imaginário social. A significativa participação da televisão no universo de produção simbólica dá a qualquer conteúdo veiculado pelo meio grande poder de capilaridade. O que é dito na televisão é visto, ouvido e levado em consideração por muita gente no Brasil.

Na TV aberta brasileira, em meio a telenovelas, programas culinários, musicais, de entrevistas, reality shows, telejornais etc., destaca-se um subgênero bem popular desses últimos: os telejornais policiais. Produtos da mídia televisiva, eles ocupam lugar preeminente nas grades e na memória imediata de grande contingente de pessoas que os assistem. Os discursos produzidos e propalados no âmbito dos telejornais policiais, evidentemente, ganham em reverberação ao serem emitidos a partir desse meio de comunicação de grande alcance.

\section{JORNALISMO, TELEJORNALISMO POLICIAL E LEGITIMAÇÃO DO ARBITRÁRIO}

O jornalismo é atividade profissional em cuja autoimagem consta, como atribuição primordial, a apuração e divulgação de "informações" pretensamente pautadas na "veracidade" e no atendimento ao "relevante interesse público" (FENAJ, 2007). Sabe-se que o jornalismo, enquanto gênero midiático, detém em suas versões televisivas os maiores índices de audiência, comparáveis, em frequência e intensidade, apenas às telenovelas.

Dentre os telejornais atualmente mais consumidos no país estão aqueles normalmente classificados como "policiais". Os principais exemplos de repercussão nacional são os programas Cidade Alerta (Rede Record) e Brasil Urgente (transmitido pela Rede Bandeirantes), produzidos por duas das maiores emissoras de televisão do país e detentores, em conjunto, dos maiores índices de audiência em seus horários de exibição. Veiculados a partir da cidade de São Paulo, nas sedes dessas emissoras, os programas são retransmitidos em rede para todo o país e têm suas versões regionais produzidas em filiais, além de servirem como referencial de linguagem e conteúdo para dezenas de outros programas congêneres nessas filiais e em emissoras de outras redes. Tamanho investimento nesse tipo de programa é evidência da confiança comercial depositada na reprodução do formato.

Uma característica distintiva do telejornalismo policial, especialmente interessante para os propósitos deste artigo, é a constante e explícita emissão de “opiniões" 
por parte de seus apresentadores. A narração da notícia - a apresentação do "fato" propriamente dito -, que é feita, no jornalismo "tradicional", com a pretenção de se obter a maior economia de análise e julgamento possíveis (SCHUdSON, 2010), no jornalismo policial fundamenta-se nas opiniões dos apresentadores, as quais costumam preencher a quase totalidade do tempo. Um mesmo acontecimento, possivelmente reportável em uma sentença curta, é anunciado, reanunciado com modificações na ordem sintática e com ênfases alternantes, é retomado, readjetivado, dramatizado em cada detalhe, comparado com eventos semelhantes etc., sempre com ênfase particular no julgamento moral, com apelo a presumíveis valores universais, mobilizados pela autoridade enunciatória dos apresentadores e "especialistas" que compõem o elenco dos programas, em uma patente busca de fácil entendimento, adesão gnoseológica e emocional por parte do público-alvo.

Encenam-se reconstituições dos eventos, rememoram-se casos similares ao que está sendo noticiado, recolhem-se depoimentos de sujeitos envolvidos direta ou indiretamente, ouvem-se pareceres profissionais de agentes públicos, de advogados, de repórteres que elaboraram a matéria e de demais membros da equipe de produção do programa. Esses elementos são a matéria-prima para a contrução de um cenário discursivo que será resumido e julgado pelo apresentador, de maneira caracteristicamente enérgica.

A própria performance do apresentador dá a ele grande visibilidade nesse tipo de telejornalismo, contribuindo para torná-lo uma estrela midiática. O destaque comercial alcançado por esses "âncoras" no interior das emissoras, graças ao sucesso de audiência dos programas, leva à concessão de maior espaço na programação e, consequentemente, ao alcance de mais prestígio perante a audiência. Tal posição de destaque dá a esses apresentadores, personificações dos valores defendidos em seus programas, status de autoridades em assuntos morais.

Ao não medirem esforços para emitirem suas opiniões sobre as notícias, os apresentadores dos telejornais policiais sintetizam, vocalizam e repercutem anseios, valores, visões de mundo e expectativas mais ou menos difusas no universo abrangido por sua audiência. A partir de suas posições privilegiadas no campo midiático, esses jornalistas conferem existência pública (BouRdiEU, 1989) e autoridade moral ao que, sem a ação deles, permaneceria contido no âmbito privado. Consolidando discursivamente e "acusando publicamente" (Bourdieu, 1989) valores que são percebidos por meio de pesquisas e através da "intuição" 
jornalística ${ }^{1}$ como hegemônicos junto aos destinatários, os telejornais policiais ocupam a posição de produtores legítimos da visão de mundo legítima para amplos setores da população brasileira. Nesse trabalho de categorização, eles fazem ver, dão existência pública e validade, consagrando visões de mundo. Nas palavras de Bourdieu, realizam um "ato de direito que consiste em afirmar com autoridade uma verdade com força de lei" (Bourdieu, 1996, p. 109). Esse ato de lei é realizado de maneira caricatural pelos "âncoras" desses telejornais, através de suas atuações sempre incisivas, em tons confessionais, professorais, investidas dos papeis autoatribuídos de "porta-vozes do povo".

Do ponto de vista desses personagens televisivos, imersos na illusio própria do campo (Bourdieu, 1989), o trabalho que fazem corresponde a retratar a "realidade como ela é" e, ao o fazerem, alertarem as pessoas e incentivá-las a cobrar do poder público, além de oferecerem os meios de canalização para essa cobrança, prestando, assim, um "serviço à sociedade" ${ }^{2}$.

\section{EFEITOS DE POSIÇÃO}

Pessoas vivendo em coletividade produzem representações sobre o mundo e, assim o fazendo, contribuem para produzir esse mundo. Essa atividade se dá dentro de circunstâncias nas quais operam constrangimentos decorrentes das posições ocupadas pelos sujeitos enquanto seres sociais no espaço de distribuição de atributos socialmente diferenciados diferenciadores (BouRdieu, 2007). As representações produzidas tendem a ter menor ou maior representatividade, alcance e eficácia coletiva a depender do sucesso das instâncias de consagração (os campos religioso, intelectual, político, midiático etc.) em realizarem seu trabalho legitimador.

Esquemas de percepção jornalísticos refletem a posição que praticantes desse ofício ocupam no espaço social, dentro do altamente heterônomo ${ }^{3}$ campo jornalístico e na relação deste com os demais, e conformam o trabalho de produção da notícia. Parte do que jornalistas produzem está determinada pelas urgências carac-

1 Saber prático adquirito pela socialização no meio, é frequentemente designada "faro jornalístico" a capacidade que certos profissionais da área têm de julgarem o "valor-notícia” (MCQUAIL, 2003, p. 345) dos eventos, presumindo-se a recepção já no âmbito da produção.

2 A noção de "prestação de serviço" é um dos valores explícitos na deontologia do jornalismo. Trata-se, no caso do telejornalismo policial, de um dos modos difusos de se reivindicar a função social da televisão, desse tipo de telejornalismo e, desse modo, de se opor tanto ao descrédito simbólico do veículo quanto ao estigma de programas comumente desclassificados sob a pecha de sensacionalistas ou "mundo-cão".

3 A heteronomia do campo jornalístico (Bourdieu, 1997) diz respeito à sua alta permeabilidade às constrições do campo econômico, como procuro evidenciar no decorrer deste texto. 
terísticas da própria atividade profissional. Essas urgências, na rotina cotidiana, adquirem vida própria e finalidade em si mesmas. Por outro lado, opera a referência aos princípios democráticos, valores acionados publicamente, sempre que julgado necessário, para justificar a prática do ofício e que se encontram consolidados nos códigos de ética e prática da profissão (regimentos, estatutos, manuais de redação etc.), documentos que recomendam atitudes como procurar "apurar os fatos com isenção", "ouvir todas as partes envolvidas" e "buscar atender o interesse público" (cf., p. ex.: FENAJ, 2007; E.в.c., 2013). Há ainda as constrições econômicas sofridas pelas empresas midiáticas, as quais, enquanto negócio, dependem da audiência a seus programas. A audiência, indicador captado por sondagens amostrais, é, afinal, o produto que essas empresas vendem às agências de publicidade, que, por sua vez, prestam serviços aos anunciantes.

Sobre as atuações televisivas dos apresentadores dos telejornais policiais operam, simultaneamente, constrangimentos que podemos conceber como advindos das rotinas da profissão (busca pelo "furo", pela exclusividade da informação, preocupação com a escassez de tempo, limitações tecnológicas e de recursos humanos, prerrogativas do cargo que ocupam na empresa, relações com fontes, com instâncias estatais e com os próprios colegas de equipe), da ética jornalística "universal" (isenção, respeito aos princípios liberal-democráticos, consciência de si próprios como "formadores de opinião") e da empresa midiática (necessidade premente de agradar a audiência a qualquer custo, desempenho dos programas concorrentes, capacidade de se atender aos anseios dos anunciantes).

Perpassando esses constrangimentos, há ainda o enquadramento dos programas dentro do "gênero". Os gêneros, categorias de percepção nativas do universo midiático, decompõem a realidade, classificando as partes decompostas como "jornalístico", “dramático", “fait divers”, "de prestação de serviço”, “opinativo”, "de entrevista", "humorístico", "esportivo", elementos cuja presença majoritária torna determinado programa um telejornal, uma telenovela, um seriado, um documentário, um "programa de variedades", de auditório, de entrevistas, um "talk show", "um programa de debates" ou a combinação de dois ou mais desses (ARONChi De SouZA, 2004). Tais categorias, graças às estratégias seguidas no âmbito da produção a fim de se comunicar com as audiências, tornam-se compartilhadas com o público, o qual, por sua vez, passa a perceber o mundo existente fora da tela, em grande parte, dentro do formato cognitivo imposto por esse princípio de visão e divisão (Bourdieu, 1996). Todos esses constrangimentos posicionais (do campo) e disposicionais (do habitus), que pesam sobre instituições e indivíduos envolvidos na produção, conformam os discursos possíveis no âmbito do telejornalismo. 
A posição dos jornalistas no campo midiático, como afinal ocorre com qualquer agente em qualquer campo, dá a eles o sentido do jogo, um conjunto de saberes práticos relativos ao que é noticiável, ao que tem valor jornalístico, mas também e sobretudo - um saber prático em relação ao que "dá certo" ou não em termos da aceitação do conteúdo e formato de seus produtos por parte da audiência. É nesse sentido que podemos dizer que os jornalistas sabem o que seus públicos querem ver e ouvir. O que está em operação é uma forma de "censura antecipada” (BourDIEU, 1996). Tanto a estrutura dos telejornais policiais como os discursos de seus apresentadores são constituídos por esse saber prático dos produtores midiáticos envolvidos e que, pelo mecanismo da censura antecipada, estão em consonância com o que as audiências dos programas esperam.

\section{DISCURSO QUE LEGITIMA VISÕES DE MUNDO}

Os esquemas de visão de mundo subjacentes ao discurso veiculado pelos telejornais policiais ressoam em sua imensa audiência também porque fazem sentido para ela. Fazer sentido não envolve apenas o reconhecimento do significado de palavras e expressões, a "clareza" na exposição, a dicção compreensível e o timbre de voz esteticamente agradável. Envolve também - e principalmente - o compatilhamento prévio dos mesmos esquemas classificatórios. Esses esquemas, dado o reforço que recebem ao serem confirmados na tela da TV, legitimam-se e são legitimados em meio a uma expressiva parcela da população brasileira.

Temos visto que o discurso no interior desses programas é "pensado" para agradar à maior quantidade de pessoas possível. Postulando-se que a tendência mais espontânea do ethos do público-alvo é o apego ao status quo, a tônica desse discurso é conservadora: inclui críticas frequentemente personalizadas aos órgãos policiais e de justiça, críticas difusas ao Estado, um clamor por punições mais severas aos "criminosos" - sujeitos normalmente caracterizados nos telejornais policiais como sendo encarnações do "mal”, em oposição polar às "pessoas de bem".

Esse discurso também envolve relativa resistência a mudanças culturais, calcada na defesa de valores tradicionais, ligados à família e à religião, a relativização de preceitos referentes à dignidade da pessoa humana, em prol dos mesmos "valores tradicionais", muitas vezes acionados nestes termos, o apego ao realismo das "provas" e à força das convicções, em detrimento da argumentação como forma de se produzir verdades sempre provisórias. Ele inclui também a descrença em relação às soluções democráticas, sejam elas representativas ou diretas, para os conflitos políticos, bem como uma generalizada desconfiança em relação à própria 
política, a personalização da crítica ao atual estado de coisas, a essencialização do comportamento humano, que é tido como um dado de natureza.

Por fim, está igualmente presente nesse discurso certo liberalismo econômico e político que tende a valorizar a livre iniciativa, o sucesso como decorrência do esforço individual, a redução da atuação do Estado, dentre outros elementos bastante difundidos no senso comum brasileiro. Mais adiante procurarei destacar a presença dos elementos acima referidos diretamente nas falas dos apresentadores dos dois principais telejornais policiais do país, Brasil Urgente e Cidade Alerta.

\section{A ESTRUTURA DOS PROGRAMAS}

As análises apresentadas aqui são parte de pesquisa empírica que realizei entre 2014 e 2015. Os programas aqui analisados continuam sendo exibidos. As mudanças ocorridas daquele momento até hoje não tornam menos atuais as conclusões a que chego, já que o formato dos programas, conteúdos veiculados e abordagem dos assuntos retratados se mantêm inalterados. A mudança principal, a qual fará com que a apresentação do material empírico seja redigida com verbos no pretérito, foi a saída de Marcelo Rezende, à época apresentador "titular" do Cidade Alerta, que faleceu em setembro de 2017, vítima de câncer. Cidade Alerta é apresentado atualmente pelo jovem jornalista Luiz Bacci, que trabalhava como repórter e também como apresentador eventual do programa aos sábados e em impedimentos pontuais do âncora titular. O apresentador do Brasil Urgente continua sendo José Luiz Datena ${ }^{4}$; o jornalista chegou a deixar esse posto, no início de 2018, para apresentar um programa de variedades nas tardes de domingo, em momento no qual inclusive cogitava publicamente a possibilidade de entrar para a política institucional, possivelmente candidatando-se ao Senado Federal ${ }^{5}$. Nesse tempo em que José Luiz Datena esteve ausente, o Brasil Urgente foi comandado por seu substituto ocasional, o filho Joel Datena. Nos casos de mudança de apresentadores, as emissoras continuam com o formato que está dando certo. Os substitutos atuam como reprodutores mais jovens, "apadrinhados" dos mais antigos.

A investigação dos discursos foi empreendida a partir da análise de edições dos programas, transmitidas em cadeia nacional no período referido. Vali-me dos

4 Afirmação válida na data de publicação deste artigo.

5 Fonte: Bergamo, Mônica. Datena diz que refletiu e será candidato ao Senado. Folha de São Paulo. São Paulo, p. 1-1. jul. 2018. Disponível em: <https://www1.folha.uol.com.br/colunas/monicabergamo/2018/o7/datena-diz-que-refletiu-e-sera-candidato-ao-senado.shtml>. Acesso em: 03 jul. 2019. 
vídeos disponibilizados nos sites das emissoras produtoras ${ }^{6}$, nas páginas oficiais dos programas no Facebook, bem como de gravações que fiz a partir das transmissões originais ocorridas em 2014 e 2015. Das muitas horas de gravação, foi feita uma inevitável seleção, norteada pelo que me pareceu ser mais representativo do conteúdo abordado nesses programas.

Tentarei explicitar as falas e atitudes dos apresentadores, comentaristas e repórteres, destacando passagens pertinentes para a argumentação. Meu intento é destacar a estrutura geral da apresentação das notícias e comentários dos apresentadores sobre elas. Apesar de me basear no conteúdo "textual”, o que implica dar menos ênfase aos gestos, sons, cenários, recursos gráficos, imagens etc.7 é importante encararmos esse texto a partir de uma análise socio-lógica, coerente com o que tenho exposto até aqui, considerando-o não como uma entidade com vida própria e com sentido em si mesma, mas como produto das condições sócio-históricas que estabelecem a posição dos agentes envolvidos em um campo de disputa pela definição dos significados (Bourdieu, 1996).

Os programas Brasil Urgente e Cidade Alerta são transmitidos para todo o território nacional ${ }^{8}$, pelas emissoras de TV Band e Record, respectivamente. Eram e ainda são concorrentes entre si, de segunda a sábado, ocupando mais ou menos a mesma faixa de horário, ao final da tarde ${ }^{9}$. Ambos tinham expressivas três horas de duração, aproximadamente, de segunda a sexta-feira, e cerca de uma hora e meia aos sábados.

Apresentado por José Luiz Datena, jornalista cinquentenário cuja carreira profissional começou na cobertura esportiva radiofônica, o Brasil Urgente existe desde 1997. A versão nacional do Cidade Alerta foi transmitida inicialmente de 1995 a 2005, pela Record. Foi retomada pela emissora durante três meses, em meados de 2011, quando inclusive chegou a ser apresentada por Datena, e voltou a ser

6 No período analisado, Band e Record disponibilizavam diariamente nos sites dos programas as íntegras das matérias apresentadas. Apenas em alguns casos também eram disponibilizados os comentários dos apresentadores, ritualmente feitos antes, durante e/ou depois de cada matéria. Muitas edições completas, bem como trechos específicos de ambos os programas, são gravados e postados por telespectadores "anônimos" em sites de compartilhamento de vídeos. Ademais, ao final de junho de 2015, a Record passou a disponibilizar a totalidade de sua programação para acesso pago on demand no Youtube. Vali-me de todo esse material, na medida do possível.

7 Para uma análise mais pormenorizada desses elementos, bem como dos recursos técnicos utilizados nos telejornais policiais, cf. OlIVEIRA, 2007.

8 Há estados cujas empresas retransmissoras locais têm suas edições regionais dos programas. Essas edições, nestes casos, dividem os horários com a versão nacional.

9 No período em que assisti aos programas para a pesquisa, Brasil Urgente começava às 16h15, todos os dias em que era transmitido. Cidade Alerta começava às 16h45, de segunda a sexta-feira e às 17h20, aos sábados. Esses horários de início dos programas costumam variar bastante ao longo do tempo, em decorrência das estratégias de composição e recomposição das grades de programação em função das flutuações percebidas nos índices de audiência. 
transmitida em 2012, ininterruptamente até o momento. De 2012 a 2017, Cidade Alerta foi comandado por Marcelo Rezende, apresentador que iniciou a carreira no jornalismo esportivo ${ }^{10}$ impresso e que, na época em que foram gravados os vídeos utilizados nesta pesquisa, já era profissional sexagenário.

Os programas são divididos em blocos, nos intervalos dos quais são exibidas propagandas comerciais aparentemente direcionadas a um público consumidor bastante variado; além dessas, e com maior frequência, há anúncios dos demais programas disponíveis nas grades das respectivas emissoras. Há ações de merchandising. Nessas, normalmente se anunciam remédios, farmácias, tratamentos e planos de saúde, o que evidencia o direcionamento específico para determinada faixa etária acima de 50 anos, de acordo com os critérios de classificação usados nas pesquisas de mercado ${ }^{11}$. Essas informações são úteis para compreendermos as condições de veiculação dos discursos no interior dos programas policiais, bem como para termos uma ideia da audiência presumida à qual são direcionados os textos examinados a seguir.

As "matérias" normalmente envolvem a narração feita pelo(a) repórter, com auxílio das imagens disponíveis e às vezes com "reconstituições do crime"; se somado, o tempo de duração desse material resulta em pequena parcela na duração total dos programas. A maior parte do tempo é ocupada pelos comentários dos apresentadores. Enquanto narram o ocorrido, julgam os envolvidos e situam o evento em um contexto mais amplo, sempre buscando vítimas e culpados, os apresentadores valem-se da incansável repetição de trechos dos vídeos das matérias, sobretudo quando esses vídeos contêm imagens "impressionantes". Os comentários são feitos enquanto se têm ao fundo imagens que se repetem indefinidamente.

Os apresentadores ocupam posição destacada na tela. Ficam de pé em frente aos monitores nos quais são destacados trechos das matérias e através das quais "entram" repórteres ao vivo. A linguagem é bastante coloquial, reservando-se o jargão jornalístico mais explícito para as "cabeças de matéria"12 e para repórteres,

10 A trajetória similar dos dois jornalistas por sí só já suscita grande interesse sociológico já que lança luz sobre as posições atuais desses agentes e ajuda a compreender suas tomadas de posição. Por limitação de espaço e escopo, entretanto, não terei condições de aprofundar essa análise no âmbito deste artigo.

11 A notícia disponível no link a seguir é uma breve amostra de como são tratados no meio publicitário esses intervalos etários de agrupamento de audências:

Kantar Ibope Media (Brasil). IBOPE Media amplia faixas etárias da pesquisa de medição de audiência de TV. Kantar Ibope Media. São Paulo, maio 2015. Disponível em: <https://www. kantaribopemedia.com/ibope-media-amplia-faixas-etarias-da-pesquisa-de-medicao-de-audiencia-de-tv-2/>. Acesso em: 03 jul. 2019.

12 "Cabeça de matéria" é termo utilizado no jornalismo. Corresponde à introdução, lida pelo apresentador, do assunto a ser tratado na matéria feita pelo(a) repórter. Trata-se de um dos poucos momentos em que o apresentador de telejornal policial lê algo durante o programa. A 
que precisam atender ao quesito concisão, uma vez que desempenham a função de apenas relatar a matéria que será apreciada pelo apresentador, esse sim detentor de ampla autoridade enunciatória. O tom da conversa é uma estratégia evidente para conseguir proximidade com o público. Os apresentadores narram as notícias e compartilham com os telespectadores suas impressões sobre o que veem e pensam, como em um bate papo entre conhecidos ${ }^{13}$. Há nítido cuidado em explicar aos telespectadores os eventos narrados, da maneira mais didática possível, e em analisar as notícias; uma preocupação em se fazer entender, que também é uma preocupação em agradar $^{14}$. As constantes retomadas dos assuntos demonstram bem essa intenção.

Todo o cenário parece ser pensado para destacar as figuras dos apresentadores, o que corrobora a afirmação a respeito da centralidade dos discursos que emitem. Não é exagero dizer: o que temos no telejornalismo policial são horas de manifestações de juízos por parte dos apresentadores, inspirados pelos elementos contidos nos poucos casos exemplares narrados nas notícias. Os casos culminam em uma "lição", que é constatada ao final. Parecem mesmo ter interesse apenas enquanto servem de mote para as performances judiciosas dos apresentadores. Estes reúnem as virtudes do didatismo, da fluência no discurso e na capacidade de se indignar em nome dos valores compartilhados com os telespectadores.

De que exatamente tratam as matérias exibidas nos telejornais policiais? No Cidade Alerta, tratam de assassinatos por traição entre casais, pedofilia, sobretudo no interior das famílias, conflitos entre celebridades ou aspirantes a celebridades, casos de emagrecimento forçado que terminaram mal, de erros médicos envolvendo a busca por um corpo perfeito, instantes espetaculares captados em vídeos que circulam na Internet; há muitos crimes passionais: filhos que matam pais, pais que matam filhos, marido traído que mata mulher e vice-versa, casal que briga e o homem divulga fotos íntimas da ex-namorada; reportam-se brigas de trânsito, casos de abuso sexual, de prisões por tráfico de drogas e apreensão de grandes quantidades de drogas, armas, celulares, dinheiro etc.

maior parte da atuação, preenchida pelos comentários, é feita de maneira "livre”, contando no máximo com as indicações da direção do programa e com a participação dos comentaristas. Mesmo essa leitura inicial costuma ser feita em tom coloquial.

13 Tanto Datena como Marcelo Rezende dirigiam-se a seus públicos valendo-se de expressões como "Meus amigos e minhas amigas...", "Meu senhor e minha senhora...", "Caros amigos e amigas da Band...", "A você que me assiste...", "Pensa comigo!".

14 Evidência da busca por uma maneira "agradável” de se trasmitir a notícia está presente em slogan utilizado pelos responsáveis para caracterizar o programa Cidade Alerta: "Informação com narrativas que fazem a diferença!” Disponível em: Recordtv (São Paulo). Programação Nacional - Cidade Alerta. 2018. Disponível em: < http://comercial.recordtv.com.br/programacao-nacional/ cidade-alerta/>. Acesso em: 03 jul. 2019. 
As matérias mais veiculadas no Brasil Urgente tratam de todos esses temas, mas também cobrem mais frequentemente enchentes na cidade de São Paulo e região circunvizinha, congestionamentos de trânsito nessas localidades, entrevistas ao vivo com agentes públicos, com vítimas em ocorrências policiais, pessoas que protagonizaram notícias reportadas em programas anteriores, acidentes de trânsito, incêndios, resgates, enfim, um conjunto de eventos que envolvem mais diretamente a coletividade, relativamente ao Cidade Alerta, que, por sua vez, tem no rol de temas mais recorrentes a violência sob perspectiva do âmbito familiar.

No Brasil Urgente se noticiam crimes e a política de segurança; há mais notícias sobre o que acontece nas ruas da cidade enquanto espaço de circulação pública. A urbe aqui é cenário e também personagem. Há mais notícias de abuso policial e, igualmente, sobre mortes de policiais em ação. Há mais matérias produzidas a partir de estatísticas oficiais, sobre problemas de circulação nas vias públicas, manifestações por punição (“Que seja feita justiça!”), reivindicações de parcelas da população, acompanhamento do andamento de investigações etc.

Nos dois programas as matérias em si raramente ultrapassam dois minutos e meio e são apresentadas dentro de uma estrutura relativamente fixa, seguindo uma mesma ordem - excetuando-se as notícias decorrentes da cobertura ao vivo, em que o caráter de maior imprevisibilidade subverte um pouco essa estrutura. Os casos começam a ser apresentados na leitura da "cabeça" da notícia"15, pelo apresentador. Com fotos das pessoas envolvidas expostas nas telas que compõem os cenários dos programas, apresentam uma "sinopse" do caso e introduzem a matéria. É comum haver comentários já nessa introdução, como uma prévia do julgamento que vai ser detalhado em momento posterior.

À "cabeça” segue a matéria propriamente dita: exibe-se um vídeo previamente gravado, que pode conter uma simulação dramática encenada por atores e narrada por uma voz em off. Na dramatização repete-se mais detalhadamente a história apresentada na introdução. Há pelo menos uma "passagem” do(a) repórter - momento em que ele(a) aparece no vídeo para "assinar" a matéria, mostrar que o material exibido é fruto de um trabalho de apuração (o que parece contribuir para a "credibilidade" da emissão). Há também a possibilidade de que o(a) repórter apareça simplesmente para preencher o tempo de vídeo, suprindo falta de imagens para cobrir alguma informação -, com a qual se intercalam "sonoras" - quando se

15 No caso de Marcelo Rezende, havia certa flexibilização já na leitura da "cabeça”. Em vez de ler, Rezende costumava "contar a história" - conforme expressão dileta do próprio apresentador - dar uma prévia do que viria na sequência, procurando envolver o telespectador no drama a partir da sugestão de pistas que seriam pormenorizadas e retomadas no decorrer da narrativa. 
transmite o áudio ambiente. $\mathrm{O}$ (a) repórter repete o ocorrido, normalmente em tom mais formal, fornece outros detalhes sobre o local do "crime", o nome do "criminoso" e do presídio onde ele está. Entram trechos de falas das pessoas envolvidas, sejam na condição de vítimas, testemunhas, "autoridades", "especialistas" e dos próprios “criminosos", os quais, já detidos, são frequentemente entrevistados de dentro das delegacias.

\section{COMENTÁRIOS E JULGAMENTOS DOS ÂNCORAS}

Terminado o vídeo com a matéria, volta-se a exibir o apresentador, que começa a comentar o que se assistiu. Para reiterar seus pontos de vista, os apresentadores podem contar com a participação ao vivo dos(as) repórteres que elaboraram a matéria - e que trazem "novos" elementos em relação ao ocorrido até o momento - e de comentaristas "especialistas" no assunto criminalidade, normalmente jornalistas veteranos na cobertura policial - como é o caso, por exemplo, de Percival, simultaneamente comentarista e personagem cômica do Cidade Alerta.

Para ocupar o tempo do programa a partir de informações e imagens finitas, às vezes escassas, e ao mesmo tempo envolver os telespectadores, é preciso repetir, recontar e, o que é mais importante, comentar. São os comentários que preenchem a quase totalidade dos programas. É quando os apresentadores assumem a autoridade a eles conferida pela posição que ocupam na estrutura do programa e ritualmente julgam os "fatos".

Abaixo passarei a citar e analisar alguns trechos dos programas em questão:

Cabeça da matéria (Cidade Alerta, 02/06/2015):

[Marcelo Rezende:] Estão distribuindo uns livros aqui... uns livros em escolas públicas... e esses livros que estão distribuindo em escolas PÚBLICAS podem virar, segundo a primeira impressão, propaganda sobre questões de sexualidade. Os livros estão sendo distribuídos em Guarulhos, a segunda maior cidade do estado de São Paulo, e a prefeitura de Guarulhos quer distribuir os tais livros de Educação Sexual... pra crianças de até onze anos, só que, segundo reza a lenda [sendo visivelmente irônico], não é bem uma questão de educação sexual. Começa a abrir um leque, sem que se tenha um amparo... de que há uma didática certa para crianças de até onze anos de idade.

Comentário 1 (neste caso feito ainda antes de se exibir a matéria): [Marcelo Rezende, indignado] Quer dizer... tanta coisa pro sujeito fazer na vida... tanta 
criança precisando ler um livro bom... o cara vai fazer um livro de sapeca-iaia ${ }^{16}$ - é de sapeca-iaiá, é!? [pergunta retórica para alguém da produção, sem esperar resposta]. Põe no Cidade! ${ }^{17}$

[Segue a matéria, na qual se ouvem uma psicopedagoga e dois vereadores oposicionistas, do município de Guarulhos/SP, a corroborarem a tese defendida pelo programa - contra a distribuição das supostas cartilhas de Educação Sexual. O "outro lado" é apresentado como sendo composto por baderneiros intransigentes, oriundos de movimentos LGBT e "coletivos feministas". Conclui-se que "apesar das críticas”, o prefeito pretende implantar as cartilhas na rede municipal.]

Comentário 2: Engraçado... tanta coisa na vida pro sujeito fazer... Sebastião? Qual era o nome do homem [prefeito de Guarulhos]? Prefeito de Guarulhos, Sebastião... e tá lá, o homem do PT... Ele podia fazer uma cartilha pra explicar por que que em alguns lugares do partido dele... por que que se mete tanto a mão no dinheiro. Ajudava muito talvez uma cartilha anti-Mensalão [...] né, já que ele tá tão preocupado em difundir uma série de coisas [...] eu acho que ele podia fazer: 'olha, como não fazer Mensalão, livro número 1'; aí entra na área de Moral e Cívica: 'número 2, como não deixar destruir a Petrobras'; 'número 3, o que fazer com o dinheiro do BNDES...' talvez [assim] ele fizesse algo melhor para a população [...] Eu, por mim, se o sujeito quiser subir no telhado e fazer sapeca-iaiá no telhado [...] como se fosse uma gata no cio gritando, desde que não me acorde, pra mim tá tudo certo. Eu não me meto com a vida dos outros [...]. Mas eu acredito que essas coisas têm que ser natural, num momento de compreensão natural da vida. Não é goela abaixo de uma criança. [...] A família que prepara. A gente não interfere na família. [...] Isso é atalho e a vida não é feita de atalhos. [...] esses livros são atalhos... que envolvem corrupção [...]

Dos aproximadamente nove minutos de transmissão do assunto no programa, a matéria dura três. O restante é preenchido pelos comentários citados acima. A recorrente estrutura do argumento, no caso em consonância com o próprio enquadramento promovido pela matéria, contempla a passagem da crítica a uma ação governamental considerada imoral à crítica ao partido do prefeito que teria proposto a política. Da crítica à ação imoral para a responsabilização dos políticos,

16 Expressão jocosa, utilizada por Marcelo Rezende para se referir ao ato sexual.

17 Bordão do apresentador, proferido enquanto aponta para o grande televisor que compõe o cenário. Era um comando para dar início ao vídeo. 
indiscutíveis inimigos comuns, eis um movimento corriqueiro na retórica dos comentários nos telejornais policiais (RIBEIRo, 2017).

Outro exemplo, dentre inúmeros que poderiam ser citados, também exibe a maneira pela qual o apresentador julgava os eventos. Em outra matéria, feita com base em gravação de celular obtida pela redação do programa junto a telespectadores, exibe-se um homem amarrado em um poste, vestindo apenas cueca, sendo chicoteado por um grupo de pessoas. De acordo com a matéria, tratava-se do linchamento de um "traficante”, em Ipatinga/MG, que havia saído da cadeia há 38 dias e que estaria cometendo pequenos "roubos" no "morro" onde morava - daí a retaliação da população. O evento estaria sendo interpretado pela polícia como "acerto de contas com o tráfico de drogas". Na legenda sobre o vídeo amador, lê-se: "Vizinhos amarram e agridem ladrão". A notícia dura cerca de seis minutos, quatro deles ocupados pelos comentários do apresentador.

Cabeça da matéria (Cidade Alerta, 23/04/2014):

[Marcelo Rezende:] Olha a imagem do homem. Me dá imagem, vamo lá. [Muda-se o tom da voz, que se torna mais enérgica:] Repare o homem no poste. Ele é um traficante. Os cara botaram ele assim. Olha lá, tão batendo nele. 'Nunca mais vou roubar... [interpretando inventivamente os gritos repetidos pelo homem que está amarrado ao poste]'Ele é um traficante. Decidiu que ia aumentar [...] as especialidades dele: começou a roubar os vizinhos. Parece que os vizinhos não gostaram. Aí o cara tá ali [...] preso com um pedacinho de corda fininho de náilon só... é mais escândalo que qualquer outra coisa. Tá gritando por quê? Eu já pedi para parar de gritar! [exige Marcelo Rezende, imperativamente, como se estivesse sendo ouvido pelo homem que aparece no vídeo]. Ele tinha saído da cadeia há menos de dois meses [...] Mostra o ladrão! Oh meu Deus, eu acho que vou amarrar todo mundo [da equipe de redação] no poste. [ironiza, ao reclamar do diretor de vídeo, como de costume] [...] Ele saiu e teve uma ideia. Disse assim: 'agora eu vou ser ladrão e traficante.' Mas os vizinhos não concordaram. Roubou uma casa, roubou outra, até que os vizinhos descobriram [...] amarraram ele no poste, o que tá errado, né. Que não é pra fazer justiça dessa maneira. Esse é um erro... mas os sujeitos disseram que não aguentavam mais. Só de queixa pra polícia já tinham dado 5328 [sic] e ninguém fez nada. Daí reles pegaram o sujeito e colocaram aí, o que é um erro. [...] Põe no Cidade! 
[Segue matéria, apresentada por uma repórter, que, diante da evidência da agressão mostrada no vídeo, contém ao máximo seu julgamento sobre o evento. Entrevista a vítima (aparentemente, dias depois do ocorrido), que relata ter sido agredida, um policial militar (“a polícia”, na fala da repórter), que alega parecer se tratar de "acerto de contas entre traficantes e usuários de drogas" e uma senhora, suposta moradora do bairro, representado os "moradores do bairro", que demanda a prisão do suposto ladrão, inclusive como conselho para o "pior não acontecer pra ele, né...”. A repórter narra que o homem agredido, um jovem de 18 anos, foi solto há 38 dias, depois de ter mais uma passagem pela prisão, dentre muitas que já havia tido, e que, desde então, estava cometendo novos furtos pelo bairro.]

Comentário: [Marcelo Rezende:] Vou te contar uma história: esse negócio tá ganhando um volume que daqui a pouco vai virar uma epidemia. Como a gente cada vez tá mais exposto ao crime, e cada vez mais o crime aumenta, e cada vez mais a justiça não condena como deveria, e a polícia não dá cabo de tudo, tá chegando num ponto em que as pessoas vão começar a fazer justiça com as próprias mãos, como nesse caso. E eu já disse: 'não há um caminho pra paz. A paz é o caminho'. E não fui eu quem disse, foi Gandhi. Mas, uma coisa eu sempre digo [...]: 'não dá pra gente trocar o caminho pelo atalho'. O atalho da barbaridade, da justiça com as próprias mãos, esse atalho só acontece nesse momento porque a gente tá completamente exposto. Não há a repressão como deveria. Não há punição como deveria. E aí virou uma pelada no meio da rua, sem hora pra terminar. O problema é que a bola é a gente, né, e os bandidos chutam a gente pra lá e pra cá. E a gente tá cansado de apanhar.

Marcelo Rezende detecta que se trata de uma "epidemia” anunciada, mas tenta justificar a prática de linchamento. O discurso é relativamente confuso, inclusive por ser improvisado, mas o que parecia por um instante ser uma crítica negativa à prática largamente difundida do linchamento torna-se uma justificação da prática. Nesse tipo de discurso, o linchamento torna-se legítimo, uma vez que se transfere a culpa pela prática de quem a executa para a situação de impunidade em que vivemos no Brasil. As pessoas que "fazem justiça com as próprias mãos" são vítimas e agem para se defender da criminalidade, já que o sistema oficial de justiça não funciona.

Situação equivalente pode ser encontrada nos comentários de José Luiz Datena. No exemplo a seguir, a defesa do linchamento também aparece - apesar 
de o fazer de maneira ainda mais escamoteada - acompanhada por um discurso com propósitos conscientizadores. Trata-se de um vídeo também aparentemente gravado por celular, onde se vê um homem estapeando e xingando outro, em inglês, dentro do que parece ser uma loja de conveniência. Algumas pessoas acompanham o evento no local. Através da locução de Datena fica-se sabendo que o episódio ocorreu em Londres, apesar de isso não fazer diferença para o apresentador, já que o mais importante é a própria imagem "impressionante" - que desperta o interesse exatamente por ser extraordinária (BouRdiEu, 1997) - e a "lição cívica" a ser extraída do caso. Um homem estaria furtando produtos na loja e os escondendo em uma bolsa, quando o dono do estabelecimento percebe a ação e passa a agredir o sujeito. A matéria nesse caso consiste apenas na repetida exibição do vídeo, acompanhada dos comentários irônicos e “cívicos” de Datena.

Cabeça da matéria (Brasil Urgente, 16/06/2015):

[Datena:] Ladrão rouba mercado e apanha de dono! O cara tava lá roubando e tal... e de repente o dono do mercado saiu correndo atrás dele [...] Cadê a cena? Deixe eu ver aí. Na tela! ${ }^{18}$

[Passa-se a exibir o vídeo do espancamento. Datena começa a narrar, atribuindo fala às personagens, e a comentar:] Olha lá, óh. O cara tá roubando...[toma-se conhecimento disso apenas através da narração, pois não é possível ver a ação do suposto ladrão]. Aí vem o dono do mercado. Olha o dono do mercado bem lá. Cadê o dono do mercado, hein? O dono do mercado pega o cara: 'Cê tá roubando aí, é? O que que cê tá roubando aí?' [o “dono do mercado” puxa a bolsa do "ladrão" e tenta abri-la.] 'Ah, tô roubando isso aqui... Ah é? Pá, pá, pá...' [O "dono do mercado" passa a estapear e xingar o outro. Datena continua a criar a dublagem]. 'Você não volta mais aqui, hein. Deixa aí e não volta mais aqui [...] Dá área daqui, porque se você voltar aqui eu vou encher sua cara de porrada de novo.' E ele vai falando e vai dando na cara do ladrão: 'Vai embora daqui.' E dá mais um. São quantos tapas, hein? [Datena passa a contar os tapas]. E o cara ainda quer levar a bolsa! [...] Esse aí com certeza não volta mais ao mercado. Ou então volta armado, né. Não façam nunca uma coisa dessas. Primeiro, porque... não pode, tem que chamar a polícia. Segundo, porque o cara pode

18 Bordão do apresentador, proferido enquanto aponta para um dos grandes monitores que compõe o cenário. É um comando para dar início ao vídeo, equivalente ao "Põe no Cidade”, dito por Marcelo Rezende. 
ficar 'P' da vida... [Datena volta a contar os tapas e a brincar com isso, reportando-se a membros da equipe do programa]. [...] Vale a pena contar os tapas aí! [o vídeo é repetido várias vezes] [...] Você não pode fazer isso porque tem que chamar a polícia, e corre o risco do cara voltar armado com um canhão $e$ meter bala na sua cara!

O vídeo vai sendo exibido e reexibido. Não se fica sabendo muito bem o contexto em que o evento ocorreu. Também não se toma conhecimento da sucessão de eventos posteriores ao ocorrido. O vídeo já é espetacular em si mesmo e por isso cabe na pauta do programa. O formato "discurso-a-partir-da-notícia" é o mesmo seguido no Cidade Alerta e, nesse exemplo em que se exibe uma situação de linchamento, o encadeamento do argumento de Datena é homólogo ao encontrado no comentário de Marcelo Rezende. Parte-se da empolgação inicial em relação à imagem e, através da locução, procura-se chamar a atenção para o caráter espetacular daquilo a que se assiste. Na sequência, passa-se a introduzir comentários ambíguos do apresentador.

A "lição cívica" que Datena transmite a seus telespectadores é a de que "Não façam nunca uma coisa dessas. Primeiro porque... não pode, tem que chamar a polícia...”. Não se bate em ladrão porque é ilegal. Deve-se chamar a polícia. Esse é o dever do cidadão. Entenda-se bem: não está em jogo a legitimidade da prática de violência física contra outro ser humano. Não se faz uma coisa dessas "apenas" porque a lei não permite. O complemento dessa "lição cívica" é igualmente racional com relação a fins: o sujeito agredido pode revidar de maneira ainda mais violenta. Nas palavras do apresentador “o cara pode ficar ' $\mathrm{P}$ ' da vida [...] e corre o risco do cara voltar armado com um canhão e meter bala na sua cara.” Há de se temer a possibilidade de retaliação. O medo da retaliaçãojustifica a adoção de determinada prática, assim como no "estado de natureza" hobbesiano.

Em matéria do Cidade Alerta, transmitida em agosto de 2015, temos a reiteração da defesa da pena capital. Na tela vê-se um homem idoso a caminhar com a ajuda de uma bengala por um lugar que parece ser uma praça.

Cabeça da matéria (Cidade Alerta, 19/08/2015):

[Marcelo Rezende:] Você vai vendo a imagem... a imagem que você está vendo é uma imagem de dar dó! A imagem de dar dó... o que que ocorre? Um homem. Um homem caminha com toda calma do mundo. Um homem com o rosto cansado. Um homem tomado pelas dores das juntas. Carregando um 
peso, aos setenta anos. A única coisa que ele não carrega de peso é o peso da consciência. Ele está sendo preso. Ele abusou das netas de quatro, cinco e seis anos de idade. Exatamente! [passa a constar no vídeo uma legenda, onde se lê: "Desmascarado: o avô maníaco"] E, também, agora é acusado de ter violentado uma das filhas, quando a filha era criança. Quando eu digo que as aparências enganam... Põe no Cidade!

[Segue a matéria. A repórter constrói uma narrativa em torno do raciocínio contido no provérbio popular "Quem vê cara não vê coração", que ela inclusive cita para analisar o caso. Ficamos sabendo que o homem foi preso em flagrante, acusado de abusar sexualmente de uma neta de seis anos. Teria sido denunciado pela própria família, a quem ameaçou com arma de fogo, caso o entregassem à polícia. O depoimento inocente da menina haveria impressionado até a delegada, acostumada a lidar com casos de violência. Uma vez preso, outras vítimas na família se encorajaram e denunciaram a recorrência de outros abusos equivalentes já cometidos pelo mesmo homem]

Comentário: [Marcelo Rezende:] Quando eu digo que não tem idade... E quando é descoberto, já cometeu outros crimes. Imagina esse homem, com essa cara... [o rosto de um senhor que usa óculos, cabelo e barba brancos, é exibido no televisor ao lado de Marcelo Rezende]. Quem vê na rua diz: 'Oh, tadinho, tá com dor na junta.' Além de massacrar a neta,já tinha massacrado a filha e a polícia tem certeza que ele tem um caminho de violência sexual. Se, na primeira vez que pegassem - é que nunca pegaram... Quando eu digo: se, na primeira vez, se tem pena de morte, três crianças estavam livres do 'avozinho', do 'vovozinho'. Imagina o trauma dessas crianças daqui pra frente. Imagina como elas vão, aos poucos, vão crescendo, se transformando em mocinha, mulher, e nunca elas vão esquecer. Portanto, quando eu digo: 'Pegou? Pegou. Comprovou? Comprovou. Tem que dar fim!' Ou seja, pena de morte ou prisão perpétua. Não pode conviver em sociedade.

A única maneira de eliminar o mal, sobretudo em se tratando de transgressões tidas por as mais imorais, como são os casos de pedofilia, é eliminando definitivamente o sujeito transgressor. Uma vez comprovado o crime, aplica-se a pena capital. Assim o fazendo, evita-se a recorrência do indivíduo no mundo do crime. O "pedófilo" é incorrigivelmente mau. Afinal de contas, no curioso exercício de previsão do passado contido no discurso de Rezende, já estava determinado como destino 
inexorável do homem abusar de outras pessoas, de modo que, eliminando-se a possibilidade da prática ao eliminar de vez o perpetrador potencial, evitar-se-ia a ocorrência do crime.

O anseio por maior punição é mesmo a tônica dos discursos dos apresentadores. Além do linchamento e pena capital, faz-se recorrentemente a defesa da redução da maioridade penal. Em junho de 2015 o tema povoou intensamente a agenda midiática no Brasil. Isso porque entrou em votação na Câmara dos Deputados uma Proposta de Emenda à Constituição que tocava na diminuição da idade a partir da qual o indivíduo passa a responder penalmente como adulto, sem o benefício das garantias asseguradas aos jovens pelo Estatuto da Criança e do Adolescente.

No Brasil Urgente o assunto foi abordado no encadeamento de matéria sobre a morte de uma jovem por complicações decorrentes do fato de ter sido estuprada, espancada e jogada de um penhasco por quatro menores de idade. Datena aproveitou o ensejo para mostrar que já vinha há muito "cobrando das autoridades" a redução da maioridade penal, para que casos como aquele não voltassem a ficar impunes. Reexibiram trecho de rápida entrevista feita pelo próprio apresentador, em 2013, com o então Ministro da Justiça, José Eduardo Cardozo. No contexto, fazia-se no programa uma "pesquisa sobre a redução da maioridade penal". O vídeo começa com a pergunta de Datena. Na legenda lê-se: "Há dois anos [fora gravada a entrevista com o Ministro]. Lei da maioridade penal se arrasta por 20 anos”.

(Brasil Urgente, 15/06/2015).

[Datena] - Ministro, a gente tá fazendo uma pesquisa sobre a redução da maioridade penal. O senhor é contra?

[Cardozo] - Olha, eu tenho afirmado que é uma cláusula pétrea, mas a gente tem que discutir quais os melhores caminhos pra isso [...] Nós temos que, nesse momento, debater - essa discussão é boa pra sociedade - e verificar que políticas nós devemos ter para enfrentar essa questão da maioridade penal.

[Datena, em tom de indignação] - Enquanto se debate, muita gente é morta por menores, Ministro.

[Cardozo] - Veja, isso acontece, mas muita gente também é morta por adultos e nós temos que enfrentar as mortes como um todo. Eu acho que nós temos que ter na Segurança Pública uma ação muito importante, corajosa... e competente. 
E não adianta ficar empurrando culpa pra um, culpa pra outro. Nós temos que estar juntos pra enfrentar o problema da violência.

[A matéria prossegue, com a narração da repórter, que diz que a entrevista havia sido gravada há "exatos dois anos [e desde então nada de positivo no tocante a esse problema social veio a acontecer]", quando Datena interrompe:]

Um segundo. [...] Foi bem colocado pela Fabíola [a repórter] ali no início da reportagem [...] porque fazem DOIS ANOS que eu entrevistei o Cardozão. Ele disse uma coisa óbvia: 'É, não é só menor que mata, é adulto que mata também.' É claro! Vocês aí em Brasília nem reduzem a maioridade penal, como também não votam projetos importantes pra tentar pelo menos atualizar esse Código Penal, que tem quase oitenta anos! [...] Agora, vocês nem melhoram o Código Penal, com medo de alguns políticos serem presos também... ou, às vezes, sei lá por quê... por omissão... sei lá o quê... os bons, por omissão, os ruins, porque são ruins mesmo, entendeu!? Vocês nem melhoram o Código Penal e nem votam a redução da maioridade penal [...]

[A fala de Datena se estende. O apresentador autoriza a retomada da matéria. O assunto da reportagem é: a redução da maioridade penal vinha sendo "debatido" há bastante tempo no programa, em decorrência das frequentes notícias de crimes praticados por menores. Em trecho da matéria aparece Datena, em outra edição do programa, tecendo seu comentário habitual:]

Quantos casos de menores matando, todo dia... Eu digo sempre aqui que a gente revela, ultimamente, por essa lei idiota que a gente tem... porque o Estatuto da Menor é muito bom pra defender o menor abandonado pela família. Não pode usar o mesmo Estatuto para defender o menor assassino, estuprador, violentador [...]

[A matéria termina e se passa a exibir a imagem de Datena, ao vivo. $\mathrm{O}$ apresentador dá seu parecer final sobre o assunto:]

Bom, eu sei lá o que esses caras [os deputados federais] vão votar, mas alguma coisa tem que ser feita. O menor não pode continuar matando e continuar impune. O menor não pode continuar violentando e continuar impune! 
A mesma constatação da "impunidade", com a recorrente crítica às "leis fracas", está presente nos comentários abaixo, acompanhada de todos os elementos que tenho tentado destacar. Está presente o mesmo movimento: da crítica à "impunidade" à crítica aos políticos e, neste caso, explicitamente, crítica à própria democracia representativa. O ensejo é dado por notícia sobre um caso de "roubo consumado seguido de morte"19:

Cabeça da matéria (Cidade Alerta, 04/06/2015):

[Marcelo Rezende:] Presta atenção na história desse moço. Ele é dono de uma empresa de informática. Casado há quatro anos. Ele é pai. Pai de um menino de três anos de idade. O que que acontece: o menininho faz aula de natação e o pai foi lá. De repente, ele [o pai] se deu conta - tá com o filho - de que esqueceu a toalha dentro do carro. Ele volta pra buscar a toalha. Resumo: lá fora estão três bandidos. Os três bandidos atiraram por atirar. Fugiram sem levar nada. E o rapaz é morto.

[Na reportagem fica-se sabendo que o homem, "um rapaz alegre com um futuro brilhante", era dono de uma empresa de informática, tinha 39 anos, e foi assassinado em Campinas/SP, quando buscava esposa e filho na academia. Aparentemente três homens abordaram o empresário enquanto ele ia ao carro buscar uma toalha para o filho. Tentaram roubar o automóvel; o empresário reagiu e foi baleado.]

Comentário: A pergunta que eu faço é: o que que a gente faz hoje em dia para realmente punir o crime? Não é possível que um sujeito que mate um chefe de família pelo simples prazer de matar seja preso e condenado por essa lei ordinária [no sentido pejorativo] do Brasil. É preciso que a gente, sociedade, que eu e você nos movimentemos. É preciso que a gente faça uma campanha... o Congresso Nacional, quando ele quer mudar a Constituição, eles inventam de qualquer maneira uma Emenda Constitucional. E quando não quer - acontece agora com a redução da idade penal - o Congresso Nacional, ou a maioria da comissão que está estudando a redução da idade penal, é a favor. Então vai votar, até porque o presidente da Câmara, Eduardo Cunha, já se disse a favor. Imediatamente, o governo Dilma, que é contrário à lei, já disse que é incons-

19 Tipificação do crime, conforme se noticia ter sido registrado no boletim de ocorrência. 
titucional. Se fosse ao contrário, aí o Congresso diria que é inconstitucional, o que é na verdade uma absoluta balela e uma absoluta baderna! Então, eu tenho certeza que eu e você temos que ter o direito... porque somos nós, eu e você, que sustentamos... essa farra que é a política brasileira - com exceções.... Somos nós. É o nosso dinheiro. E a gente tem que ter o direito, o direito da gente escolher o que a gente quer pro nosso país. Porque os homens que estão no Congresso - registro, há exceções - boa parte vende voto de cabresto, voto por troca de favor... isso não é uma representatividade do cidadão. Não é possível que três sujeitos que matem num assalto um pai de família, se presos, fiquem doze, treze anos na cadeia, não! Eles tinham que ser condenados a pena de morte pela barbaridade cometida!

Mais que pena de morte ou prisão perpétua, como punição ao "criminoso" sugere-se também o castigo nos mesmos termos do dano causado.

Cabeça da Matéria (Cidade Alerta: 08/06/2015):

[Marcelo Rezende:] Hoje aqui em São Paulo aconteceu um crime, que foi filmado, e ninguém conseguiu falar com o sujeito. Um sujeito que namora uma moça, ele acreditou que estava sendo traído [...] Eu vi a imagem. Aquilo me deu uma irritação - e olha que pra me irritar eu demoro. [...] Há uma imagem desse sujeito batendo na namorada. Ele pagou fiança e ficou livre. O que que acontece: a Fabíola ${ }^{20}$ o encontrou e falou com ele [...]

Comentário 1: Como pode um sujeito desse tamanho bater numa mulher [...] Eu vou dizer uma coisa pra você, em toda sã consciência: um sujeito desse devia... devia ter um negócio assim que ele pudesse apanhar, né. Porque a polícia chegou lá e tem que prender. E ele encontrou a repórter e deu gargalhada! [...] Pra ele tá tudo certo!

[Na matéria mostra-se um homem batendo em uma mulher, sobre a calçada. O vídeo da agressão foi capturado por uma câmera de segurança da Guarda

20 Fabíola Gadelha. Tratava-se de uma repórter do programa. Ficou famosa como repórter da versão regional do Cidade Alerta, em Manaus/AM, por abordar de maneira inquisidora os "bandidos", julgando-os rispidamente enquanto os entrevistava dentro de delegacias. Adquirida a notoriedade na filial, foi contratada pela TV Record de São Paulo e costumava substituir eventualmente Marcelo Rezende na apresentação do Cidade Alerta "nacional”. 
Metropolitana, o que possibilitou que o a polícia chegasse poucos minutos depois. Tratava-se de um casal de namorados. O homem, que suspeitava ter sido traído, "tinha fama de violento na região" e histórico de comportamento violento com a namorada. A repórter entrevista e caracteristicamente acusa o homem à porta do que parece ser a casa dele. Passa-se, então, a filmar o estúdio, de onde Marcelo Rezende questiona a repórter e pede para que ela reconte a "história" em maiores detalhes.]

Comentário 2: A minha tese é muito simples: um cara que faz isso com uma mulher, ele tinha... devia ter um negócio que fosse assim: olho por olho, dente por dente! Bateu em mulher, apanha! Porque, se vai um cara pra cima dele, eu duvido que ele teria essa euforia toda! Mas com mulher eles têm. Eu vou te contar! Eu vou te dizer bem legal: tinha que pegar, tinha que meter numa cadeia e... Aí não. Aí a lei vai lá - a culpa não é nem do delegado - a lei vai e diz o seguinte: que ele paga uma fiança [irrisória e é solto] [...]. Pode!?

Nos julgamentos feitos a partir das notícias, os apresentadores atuam como verdadeiros inquisidores dos fatos (OlIVEIRA, 2007), procurando antecipar a justiça formal. E, como mostra Ribeiro (2017), em grande parte das vezes esses julgamentos encontram aceitação irrestrita entre aqueles que assistem aos programas, o que inclusive atesta nesses casos a eficiência das instâncias produtora e veiculadora em falarem a língua e aos anseios de seu público-alvo.

\section{CONSIDERAÇÕES FINAIS}

Neste trabalho procurei destacar fatores condicionantes da produção de certa visão de mundo moralista e punitivista através dos telejornais policiais no Brasil. Para ir além da simples atribuição da pecha de "sensacionalistas" a esses programas, deve-se procurar verificar os constrangimentos do campo profissional a que estão submetidos ao fazerem o que fazem, além de analisar parte do conteúdo que produzem.

Muitos produzem opiniões na sociedade contemporânea. Jornalistas compõem um grupo de especialistas nessa atividade. Poucos, porém, conseguem repercussão massiva. Os que o conseguem, em contexto hodierno, o fazem ainda em grande medida através dos meios de comunicação de massa ${ }^{21}$. A televisão, empregadora

21 Uso a locução adjetiva "de massa" por dois motivos principais. Por um lado, para destacar o caráter pretensamente indiferenciado do público a que no geral se destinam os produtos transmitidos em meios como a TV. Nesse sentido, a comunicação "de massa" é diferente daquela "de 
de grande número de jornalistas, detentora de recursos econômicos e concessão estatal para atingir amplas parcelas da população e manter esses produtores em atividade full-time, tem o privilégio de (re)produzir certo senso comum reinante. É inclusive útil para a empresa midiática (re)produzir esse discurso, uma vez que o sucesso comercial - que, afinal, paga os salários dos produtores, põe à disposição deles os recursos técnicos e, assim, mantém a empresa em funcionamento - depende do investimento publicitário, que, por sua vez, depende da audiência consumidora que se é capaz de manter.

Os julgamentos feitos pelos âncoras dos telejornais policiais não buscam uma compreensão "desinteressada" do mundo. A verborragia precisa ser efusiva, ao gosto do espetáculo, para atrair esse estrato do público. Com essa necessidade de comunicação rápida, enfática e ao mesmo tempo agradável, inevitavelmente impera o lugar comum, isto é, os raciocínios pré-construídos, disponíveis à reflexão mais imediata, que vêm à mente quase que sem esforço.

Busquei destacar no "texto" produzido cotidianamente no interior dos telejornais policiais alguns temas frequentes, bem como as inflexões mais comuns nas abordagens desses temas. Com este esforço, concluo ser possível afirmarmos que o telejornalismo policial, estudado neste artigo através de seus representantes de maior sucesso, condensa, amplifica, repercute e, assim, legitima, certo senso comum moralista e punitivista, amplamente difundido na sociedade brasileira e manifesto caricaturalmente nos anseios por punição e por correção autoritária das "mazelas sociais".

\section{REFERÊNCIAS BIBLIOGRÁFICAS}

Aronchi De Souza, José Carlos. Gêneros e formatos na televisão brasileira. São Paulo: Summus, 2004.

Bourdieu, Pierre. O poder simbólico. Lisboa: Difel, 1989.

A economia das trocas linguísticas: o que falar quer dizer. São Paulo: Edusp, 1996.

. Sobre a televisão. Rio de Janeiro: Jorge Zahar, 1997.

. A distinção: crítica social do julgamento. São Paulo: Edusp; Porto Alegre:

Zouk, 2007.

nicho", reconhecidamente direcionada a segmentos mais específicos de mercado. Por outro lado, a locução especifica um tipo de comunicação no qual há uma instância monopolizadora dos recursos de produção e divulgação em larga escala e em que o destinatário, apesar do crescente poder de interagir com o emissor, é em grande medida agente que apenas reage a partir do que lhe foi apresentado pelo ente produtor privilegiado. 
E.в.C. - Empresa Brasil de Comunicação. Somente a verdade: manual de jornalismo da EBC. Brasília, 2013.

Fenaj - Federação Nacional dos Jornalistas. Código de Ética dos Jornalistas Brasileiros. Vitória, ago. 2007. Disponível em: http://www.fenaj.org.br/federacao/cometica/ codigo_de_etica_dos_jornalistas_brasileiros..pdf. Acesso em: 03 de julho de 2019. HALL, Stuart et al. "The social production of news". In: HALL, Stuart et al (orgs.) Policing the crisis: mugging, the state, and law and order. London: The Macmillan Press, 1978, p. 53-77.

McQuaIL, Denis. Teoria da comunicação de massas. Lisboa: Fundação Calouste Gulbenkian, 2003.

OliveIra, Danilo Duarte. Jornalismo policial na televisão: gênero e modo de endereçamento dos programas Cidade Alerta, Brasil Urgente e Linha Direta. Dissertação (Mestrado em Comunicação Social). Programa de Pós Graduação em Comunicação e Culturas Contemporâneas, Universidade Federal da Bahia. Salvador, 2007.

Ribeiro, Fábio R. A. Telejornalismo policial, senso comum e classe social. Curitiba: Prismas, 2017.

Schudson, Michael. Descobrindo a notícia: uma história social dos jornais nos Estados Unidos. Petrópolis: Vozes, 2010.

Thompson, John B. A mídia e a modernidade: uma teoria social da mídia. Petrópolis, RJ: Vozes, 1998. 